
\title{
3 Research Square \\ The role of an encapsulin nanocompartment in resisting silver ion stress
}

\section{Chong-Yang Xing}

University of the Chinese Academy of Sciences

\section{Teng-Fei Ma}

Chongqing University

Jinsong Guo

Chongqing University

\section{Yu Shen}

Chongqing Technology and Business University

\section{Peng Yan}

Chongqing University

\section{Fang Fang}

Chongqing University

You-Peng Chen ( $\nabla$ ypchen@cqu.edu.cn )

Chongqing University https://orcid.org/0000-0002-7332-7464

\section{Research}

Keywords: Compartmentalization, Protein cage, Encapsulin nanocompartment, Self-assembly, Synthetic biology, Silver ion, Proteomics

Posted Date: December 13th, 2019

DOI: https://doi.org/10.21203/rs.2.18757/v1

License: (c) (i) This work is licensed under a Creative Commons Attribution 4.0 International License.

Read Full License 


\section{Abstract}

\section{Background}

Compartmentalization can protect cells from the interference of external toxic substances and sequester toxic products. We hypothesis that the proteinaceous compartments may be a candidate material with engineering feasibility suitable for adding to engineering bacteria for the sequestration of toxic environmental products, contributing to open up a new biological detoxification pathway.

\section{Results}

Here, we found a new approach of bacterial resistance to silver ion stress. We show that the selfassembled nanocompartments can help model species (E. coli) resist silver ion stress. Transmission electron microscopy and energy dispersive X-ray (TEM-EDX) analysis showed that the nanocompartments stably combined with silver ions in vitro. In addition, when exposed to $30 \mu \mathrm{M} \mathrm{AgNO}_{3}$, the survival rate of engineered bacteria (with nanocompartments) was $86 \%$, while it was just $59 \%$ in the wild-type bacteria (without nanocompartments). Moreover, label-free quantitative proteomics indicated that the nanocompartments enhanced bacterial activity by inducing the up-regulation of protein processing and secondary metabolites, and decreased intracellular silver ion concentration, increasing resistance to toxic silver ions.

\section{Conclusions}

This study of nanocompartments contributes to a deeper understanding of how bacteria respond to environmental stressors like heavy metal pollutants in water, soil, and sediment. The encapsulin nanocompartment has the potential to be applied in different environments, potentially the human body, and appears conducive to developing new anti-toxic drugs for metal ions.

\section{Background}

In the long-term evolution of bacteria, they have developed strict procedures and automatic controls for their metabolic system. Bacteria have a robust molecular regulatory mechanism, which can effectively resist changes in the external environment[1-3]. Bacteria have also evolved a set of efficient detoxification mechanisms, which effectively detoxify heavy metal ions, thus limiting the effect of harmful heavy metal ions on their life activities [4]. In addition, bacteria have many interesting biochemical and metabolic processes. For example, selenium-rich yeast can absorb selenium compounds from the external environment and reduce the toxic inorganic selenium to organic selenium compounds through intracellular metabolism, so as to protect itself from the influence of the external environment[5, 6]. High state of toxic heavy metal ions can be reduced to their low valence states, making them less harmful [7]. For example, $\mathrm{Ag}+$ can be converted into low toxic elemental $\mathrm{Ag}^{0}$ [8]. Here, we describe a new approach to increasing bacterial resistance to silver ion stress. 
Compartmentalization can protect cells from the interference of external toxic substances and protect enzymes in cells from proteolysis[9]. Both the lipid-binding organelles of eukaryotes and the protein containers of prokaryotes have this property[10-12]. Protein cage is a common biocompatibility system that has been found in many fields, especially as a carrier[13,14]. The addition of similar protein cages in engineered organisms may result in significant improvements in sequestering toxic environmental products. Therefore, we hypothesis that the proteinaceous compartments may be a candidate material with engineering feasibility suitable for adding to engineering bacteria for the sequestration of toxic environmental products, contributing to open up a new biological detoxification pathway.

There are many examples of compartments in nature, such as lipid-binding organelles in eukaryotes and protein containers in prokaryotes[10-12]. One of the newest types of proteinaceous compartments is the encapsulin nanocompartment, which shows great potential for application in nanobiotechnology. In previous experiments, we used molecular cloning techniques to express the encapsulin proteins of the anammox bacteria "Ca. Brocadia fulgida" in Escherichia coli (unpublished observations). The encapsulin protein was able to self-assemble into a nanocompartment within E. coli. In preliminary studies, we found that nanocompartments helped the bacteria resist the stress of toxic products, such as hydroxylamine. This agreed with reports that the interior and exterior surfaces of the nanocompartments can be used as toxic attachment points $[15,16]$. Therefore, we speculated that the nanocompartments will help bacteria resist the stress of other toxic substances such as toxic silver ions as well. In addition to its characteristics and functions, evidence has shown that nanocompartments can be easily manipulated through genetic engineering, significantly increasing the number of potential applications[17].

To better understand the protective mechanisms of nanocompartments, silver ions were used as a model toxin. Industrial wastewater releases a large number of harmful heavy metals into the environment, including $\mathrm{Ag}+$, which can cause great harm to the ecosystem and human health, in addition to wasting a valuable resource[18]. Ag+ can enter the human body through aquatic organisms, which can lead to a variety of diseases as it accumulates[19,20]. Therefore, finding a suitable method to remove $\mathrm{Ag}+$ from wastewater is urgently needed, and of great significance for the continued recovery from and treatment of wastewater pollutants.

In this study, transmission electron microscopy and energy dispersive X-ray spectroscopy (TEM-EDX) were used to determine whether the nanocompartments were able to combine with silver ions in vitro. Next, we used surface plasmon resonance imaging (SPRi) technology to characterize the kinetic process of the combination of silver ions with the nanocompartments. Lastly, label-free quantification proteomics was used to reveal the antibacterial mechanisms of silver ions with high resolution at the protein level. This study has increased our understanding of the role that nanocompartments play in reducing cellular stress caused by silver ions.

\section{Results}

\section{Nanocompartments encapsulate silver ions in intro}


A general feature of nanocompartments is their high stability, which enables them to endure in culture supernatants[21, 22]. An encapsulin nanocompartment resembles a virus capsid in terms of its mechanical properties. In order to determine whether the nanocompartments can encapsulate silver ions, we incubated the purified nanocompartments with silver ions in vitro. It was found that the nanocompartments did encapsulate silver ions, appearing darker than nanocompartments without silver ions when observed by transmission electron microscopy (TEM) (Fig. 1A and B). Energy dispersive X-ray (EDX) analysis also detected silver ions in the nanocompartment (Fig. 1C, D and E), confirming that a single nanocompartment can stably encapsulate silver ions in vitro.

\section{Agglomeration/dispersion of nanocompartment encapsulated silver ions}

We have shown that nanocompartments can encapsulate silver ions, but the encapsulation process cannot be dynamically observed. So we used SPRi, which is an unlabeled in-situ detection technique[2325], to quantify the agglomeration of nanocompartments and silver ions. SPRi was conducted using a high aperture optical objective[26, 27]. Supporting Information Fig. S1 shows that when nanocompartment and silver ions were combined, they attached to the coated sensor chip, but the nanocompartment without silver ions did not attach to the surface of the chip. Fig. $2 A$ and $B$ show the transmission and plasmonic images of the nanocompartment particles with silver ions, it should be noted that the plasma image is V-shape.

It has been reported that the stability of a nanocompartment is dependent on the $\mathrm{pH}$ values[21]. Apart from $\mathrm{pH} 3$ and $\mathrm{pH} 4$, the nanocompartment particles can be stable at $\mathrm{pH} 5-9$, which is in agreement with the previous reports $[28,29]$. In our system, the nanocompartment particles were able to attach to the surface, but were also allowed to agglomerate/disperse. So, the buffer $\mathrm{pH}$ was reduced from 7 to 4 and the particles were incubated for $750 \mathrm{~min}$. Fig. $2 \mathrm{C}$ shows the agglomeration/dispersion information of the nanocompartment particles with encapsulated silver ions, this represents the first ever sensorgrams of nanocompartment particles. At pH 7, the SPRi signal increased over time, which was likely caused by the combination of the nanocompartments with silver ions. The nanocompartments landed on the surface of the sensor chip, resulting in the increased SPRi signal. When the $\mathrm{pH}$ of the solution was changed to 4 , the SPRi signal decreased over time, suggesting that the nanocompartment particles were dispersing and the silver ions were being released back into the solution (see the Supporting Information Animation, Additional file 2). In order to provide further evidence supporting our hypothesis, the surface of the sensor chip was analyzed by scanning electron microscopy (SEM-EDX). The measured points included nanocompartment particles as well as other sections of the sensor chip (Fig. 2D and E). Empty encapsulin nanocompartments could not be observed by SEM. It was found that there were silver ions where there were nanocompartment particles, but sections without nanocompartments did not have silver ions.

\section{Nanocompartment centered resistance to silver ion stress in model organism}

Our experiments have shown that the nanocompartments were able encapsulate silver ions, but it is not known whether they can protect normal bacteria from the effects of silver ions. So, we used E. coli as a 
model organism to explore the functions of nanocompartments in resisting silver ions. The process of silver ions binding to $E$. coli BL21 that were immobilized on the surface of the sensor chip was imaged using the surface plasmon resonance microscope. Supporting Information Fig. S2 shows that the E. coli BL21 cells were tethered to the sensor chip via relatively weak noncovalent bonds. Fig. 3A and B show the transmission and plasmonic images of the bacterial cells. The V-shape formed by a single bacteria matches the position of the bacteria in the optical image[26].

Then the effects of silver ions on E. coli BL21 were studied by adding $\mathrm{AgNO}_{3}$ (final concentration $20 \mu \mathrm{M}$ ). To test whether the nanocompartments were effective in bacteria, we established two different types of bacteria, using genetic and molecular biology methods. One of them was engineered bacteria (EB, with nanocompartments), and the other was wild-type bacteria (WB, without nanocompartments). Then we passed a solution of $\mathrm{AgNO}_{3}$ through the bacteria at a rate of $3 \mu \mathrm{l} / \mathrm{s}$ for about 1,000 seconds. With the addition of silver ions, the image intensity of the bacteria increased significantly. There was also a significant difference in the image intensities of EB and WB (Fig. 3C). The intensity of the image signal was proportional to the mass density of the sensor surface. So, the data showed that silver ions were absorbed by the bacteria cells. These observations also showed that the nanocompartments placed in normal bacteria can also encapsulate silver ions.

It has been reported that silver ions can damage cell membranes and DNA by producing reactive oxygen species (ROS)[30]. We speculated that nanocompartments would reduce the sensitivity of bacteria to silver. To verify this, we investigated the effects of nanocompartments on the survival of $E$. coli under ROS stress caused by silver ion exposure. Shown in Fig. 3D, as the concentration of silver ions increased, the bacterial survival rate decreased. When exposed to $30 \mu \mathrm{M} \mathrm{AgNO}_{3}$, the survival rate of EB was $86 \%$, while WB's survival rate was 59\%, which suggested that EB had a higher resistance to silver ions than WB.

\section{The possible mechanisms by which bacteria resist silver ion stress using nanocompartments}

To further explore the protective effects of nanocompartments in bacteria, the effects of nanocompartments on the growth curve of $E$. coli experiencing silver ion-caused ROS stress was investigated. As shown in Fig. 4A, the beginning of Phase I the growth curves of $E$. coli from all groups were similar. However, in Phase II, following dosing with silver ions (WB $+0 \mu \mathrm{M} \mathrm{AgNO}{ }_{3}(\mathrm{WB}), \mathrm{WB}+120 \mu \mathrm{M}$ $\mathrm{AgNO}_{3}\left(\mathrm{WB}+\mathrm{Ag}^{+}\right)$, and $\mathrm{EB}+120 \mu \mathrm{M} \mathrm{AgNO}{ }_{3}\left(\mathrm{~EB}+\mathrm{Ag}^{+}\right)$, the growth rates in $\mathrm{WB}+\mathrm{Ag}^{+}$and $\mathrm{EB}+\mathrm{Ag}^{+}$were lower than that in WB (Fig. 4A). Notably, when both were exposed to silver ions, the growth rate of the engineered bacteria was faster than the wild-type bacteria, which is consistent our previous result (the survival rate of EB is higher than WB). As predicted, the encapsulin protein (about $42-\mathrm{kDa}$ ) was found to be highly expressed in a band from engineered bacteria when analyzed by sodium dodecyl sulfate polyacrylamide gel electrophoresis (SDS-PAGE)(Supporting Information Fig. S3). These results support the hypothesis that nanocompartments help bacteria resist silver ion stress.

High-throughput proteomics was used to get a comprehensive picture of the proteomic changes in the $\mathrm{WB}, \mathrm{WB}+\mathrm{Ag}^{+}$, and $\mathrm{EB}+\mathrm{Ag}^{+}$groups. As shown in Fig. 4B, a total of 2679, 2680, and 2653 proteins were 
expressed in $\mathrm{WB}, \mathrm{WB}+\mathrm{Ag}^{+}$, and $\mathrm{EB}+\mathrm{Ag}^{+}$, respectively. Among them, 2440 proteins were shared by all three groups, suggesting that the majority of the proteins didn't change among the three groups.

In order to clarify the function of differentially expressed proteins in $\mathrm{WB}, \mathrm{WB}+\mathrm{Ag}^{+}$, and $\mathrm{EB}+\mathrm{Ag}^{+}, \mathrm{Gene}$ Ontology (GO) annotation analysis was used to analyze the quantified proteins. $G 0$ annotations analysis includes biological processes, cellular components, and molecular functions. As shown in Fig. 4C and D, in the biological process category, many of the differentially expressed proteins were involved in cellular processes, metabolic processes, and single-organism processes. It indicated that silver ions can inhibit many catabolic processes and some biosynthetic processes in bacteria. These results suggested that silver ions have intrinsic function as toxic metals.

In terms of cellular components, a large number of the up-regulated proteins were from cell parts. Intriguingly, up-regulated proteins, not down-regulated proteins, were were more commonly associated with cell membrane components. In E. coli, it has been found that silver ions affect membrane proteins, leading to cell lysis[31]. In terms of molecular functions, the up-regulated proteins and down-regulated proteins were mainly concentrated in catalytic activity and binding, suggesting that differentially expressed proteins were involved in protein processing.

We then performed $\mathrm{GO}$ enrichment analysis of up-regulated proteins between specific groups, i.e. 'WB+Ag ${ }^{+}$vs $W B$ ' and ' $E B+A g^{+}$vs WB'. As shown in Fig. $5 A$ and $B$, we identified that the $G 0$ terms "structural constituent of ribosome" and "integral component of plasma membrane" were significantly enriched among the up-regulated proteins in ' $\mathrm{WB}+\mathrm{Ag}^{+}{ }^{+} \mathrm{vs} \mathrm{WB}^{\prime}$. These results suggested that wild-type bacteria responded to the silver stress by increasing the expression of ribosome-associated proteins and membrane proteins, without success. We then found that the GO terms "single-organism transport" and "integral component of plasma membrane" were significantly enriched among the up-regulated proteins in ' $\mathrm{EB}+\mathrm{Ag}^{+}$vs WB'. Interestingly, the $\mathrm{GO}$ term "single-organism transport" was significantly enriched in the ' $\mathrm{EB}+\mathrm{Ag}^{+}$vs WB', but not in the 'WB+Ag${ }^{+}$vs WB'. These results indicated that engineered bacteria likely have other ways of regulating silver ion stress, ways which have been proven successful.. Therefore, we hypothesized that nanocompartments induced the up-regulation of transporter proteins in bacteria, thus helping to transport silver ions out of cells, thereby reducing the silver ion stress.

We then subjected the up-regulated proteins identified in ' $\mathrm{WB}+\mathrm{Ag}^{+}$vs $\mathrm{WB}$ ' and ' $\mathrm{EB}+\mathrm{Ag}^{+}$vs $\mathrm{WB}$ ' to KEGG pathway enrichment analyses. Among the enriched KEGG pathways from ' $\mathrm{WB}+\mathrm{Ag}^{+} \mathrm{vs} \mathrm{WB}^{\prime}$ ', we identified 5 significantly enriched metabolic pathways $(P<0.05)$ including the "ribosome", "protein export", "bacterial secretion system", "phosphotransferase system", and "oxidative phosphorylation" (Fig. 6A). Of the 12 significantly enriched metabolic pathways from ' $\mathrm{EB}+\mathrm{Ag}^{+} \mathrm{vs} \mathrm{WB}^{\prime}, 5$ were shared with ' $\mathrm{WB}+\mathrm{Ag}^{+} \mathrm{vs}$ WB', and 7 were unique (Fig. 6B). Therefore, those 7 metabolic pathways may be crucial in helping bacteria resist silver ions. Those 7 metabolic pathways were "fatty acid degradation", "valine, leucine and isoleucine biosynthesis", "butanoate metabolism", "starch and sucrose metabolism", "pantothenate and 
CoA biosynthesis", "caprolactam degradation", and "limonene and pinene degradation". These results indicated that detoxification was associated with protein processing and secondary metabolites.

\section{Discussion}

\section{Silver ion may enter the nanocompartments through pores}

In nature, there are several proteins that are able to carry or sequester metal ions and minerals. As reported by N. Dennis Chasteen, a multi-subunit protein shell can store iron[32]. For the protein shell to transport metal ions and small organic molecules, small channels located in the protein shell are required[33]. Sutter reported that the nanocompartment of Thermotoga maritima was a thin icosahedral shell that consisted of 60 units[34] and that the interior of the nanocompartment contained conservative binding sites. In this study, we have shown that nanocompartments do indeed serve as a platform for the absorption of heavy metal ions. The experiments presented in this paper, by transferring nanocompartments into $E$. coli (engineered bacteria) and dosing with silver ions, demonstrated that nanocompartments can encapsulate silver ions in vitro. Similar structural analyses of nanocompartments from Thermotoga maritima and Pyrococcus furiosus have also shown that capsids have multiple pores that can control the exchange of small molecules[34, 35]. These small openings likely serve as a permeability barrier to larger molecules, while permitting the transit of small molecules and ions through the shell[9]. We hypothesized that the silver ions, like the small molecules and ions mentioned above, might have entered the nanocompartments through pores.

Interestingly, we also found that the nanocompartments can encapsulate other metal ions, such as zinc ions (Supporting Information Fig. S4). Potential detoxicate nanomaterials can be prepared by taking advantage of the characteristics of the outer and inner surfaces of nanocompartments $[15,16]$. Nanocompartments can be easily manipulated by genetic means, resulting in a large number of diverse and complex potential applications[17]. Expanding upon the ability of nanocompartments to encapsulate metal ions, we speculate that they may be applied as detoxicants, with the potential to be developed into detoxification materials and drug carriers for use in industry and pharmaceuticals.

\section{The nanocompartment can encapsulate silver ions in bacteria}

In this study, we observed that silver ions reduced the growth of E. coli bacteria (Fig. 4A). Interestingly, we saw that engineered bacteria had higher survival rates than wild-type bacteria, indicating that nanocompartments increased bacterial resistance to silver ion stress. Previous studies have reported that silver ions reduce cell activity by inducing ROS production in cells or by directly destroying cell membranes[31]. Paulsen reported that bacteria may reduce high metal ions to a zero valence state to deal with heavy metal stress[7]. Our results suggested that the nanocompartments encapsulated the silver ions, effectively reducing the concentration of free silver ions in the cell, and protecting the cell. This may be a new way for bacteria to respond to environmental metal ion stress.

\section{The possible mechanisms by which nanocompartments help resist silver ion stress}


Moreover, our study has provided a comprehensive look at cellular responses to silver ion stress in wildtype and engineered bacteria at the proteomic level, and we saw changes in the ribosome, protein export system, and the phosphotransferase system, to name a few. In agreement with previous findings[36], some complexes were even able to transport $\mathrm{Ag}^{+}$from the inside to the outside of the cell.

Consistent with previous reports[37], we also found that a number of enzymes that metabolize fatty acids were up-regulated only in the engineered bacteria. These enzymes included the fatty acid oxidation complex (fadB), 3-ketoacyl-CoA thiolase (fadA, fadl), and long chain fatty acid-CoA ligase (fadD)

(Supplementary Excel file, Additional file 3). Interestingly, in contrast with previous findings and the notion that the tricarboxylic acid (TCA) cycle and the adaptive oxalate pathway are suppressed in response to silver ion stress[37], we detected up-regulation of numerous proteins involved in secondary metabolites and protein processing, but only in the engineered bacteria.

So, in engineered bacteria, silver ion exposure could increase bacteria ROS production and membrane permeability; but in the presence of nanocompartments bacteria may up-regulate protein processing and secondary metabolites, and thereby decrease the intracellular silver ion concentration (Fig. 7). This study of nanocompartments has increased the depth of our understanding of how bacteria adapt to environmental stress, and further helps to understand how bacteria deal with heavy metal pollutants in water, soil, and sediment. In addition, nanocompartments can be imported into functional bacteria by genetic engineering to remove toxic metal ions and may be applied in many industries.

\section{Conclusions}

In conclusion, we have demonstrated that the self-assembled encapsulin nanocompartment can be transferred into $E$. coli to help bacteria resist silver ion stress. However, it is not clear for how silver ions get inside or stick to the surface of the encapsulin nanocompartments, which will be the focus of our future work. Our study of self-assembled encapsulin nanocompartments provides a new approach to bacterial responses to environmental stressors like heavy metal pollutants in water, soil, and sediment. The encapsulin nanocompartment has the potential to be applied in different environments, potentially the human body, and appears conducive to developing new anti-toxic drugs for metal ions.

\section{Methods}

\section{Expression and purification of encapsulin proteins}

The encapsulin gene (cEnc) (NCBI: KK018403.1) from anammox bacteria "Ca. Brocadia fulgida" was cloned into a pET28a. The pET28a-cEnc was transferred into E. coli BL21 cells by electroporation. Detailed methods regarding protein expression are given in the supplementary information. Proteins were purified based on previously reported methods[38].

\section{SPR imaging}


First, the right chip was selected and its surface was functionalized (supplementary information). Cleaned chips were submerged in a $3 \%$ solution of APTES in ultrapure water for 1.5 minutes, then rinsed with ultrapure water prior to gentle, dust-free drying in air[39]. The coated chip was then cleaned with deionized water and ethanol and dried with nitrogen. The processed chip was then placed on the microfluidic device as described in previous relevant reports[26, 27, 40]. A FlexiPerm reusable well (Su Zhou) was mounted on top of the APTES-functionalized gold chip and filled with $500 \mu \mathrm{L}$ of $20 \mu \mathrm{M}$ $\mathrm{AgNO}_{3}$. Pump and flow rate regulato the sample cell microchannel were made of polydimethylsiloxane (PDMS) material. The size of the microchannel was $8 \times 1 \times 0.1(\mathrm{~mm})$. The model of microannotation pump was LSP01 (LTD, China). Image acquisition and experimental details are attached in the supplementary information. For better visualization, images were converted to scaled color images.

\section{SEM-EDX and TEM-EDX}

For SEM-EDX, the morphological properties of the surface and elemental distribution of nanocompartment particles (from SPRi chip) were observed using cold-field emission SEM (JSM-7800F, JEOL, Japan) and EDX (Quantax, Bruker, Germany) after gold-plating at an accelerating voltage of $20 \mathrm{kV}$.

For TEM-EDX, different nanocompartment particles (supplementary information) were measured with the settings: acceleration voltage $300 \mathrm{keV}, 5 \mathrm{eV} / 17 \mathrm{l} \mathrm{s}$, spot size 8, dwell time $60 \mathrm{~s}$ (Tecnai G2 F30, FEI Company, USA) using ES vision software (Emispec Systems, Inc, Tempe, USA).

\section{Cell survival test}

The wild-type bacteria and engineered bacteria were inoculated into LB medium. The cultures were grown to an OD600 of 0.6 . For engineered bacteria, protein production was induced with $0.1 \mathrm{mM}$ IPTG and the cultures were incubated at $37^{\circ} \mathrm{C}$ and $180 \mathrm{rpm}$ for $18 \mathrm{~h}$ in the dark. The next day, the wild-type and engineered bacterias were seeded in a 96-well plate to $10^{-4} \mathrm{CFU} / \mathrm{mL}$ and incubated in LB medium with varying concentrations of $\mathrm{AgNO}_{3}(0 \mu \mathrm{M}, 10 \mu \mathrm{M}, 20 \mu \mathrm{M}$, and $30 \mu \mathrm{M})$ at $37^{\circ} \mathrm{C}$ for $12 \mathrm{~h}$ in the dark. Five reduplicate wells were used for each treatment, and experiments were repeated three times. The experimental data was normalized for comparison.

\section{Determination of the cell growth curve}

The wild-type bacteria and engineered bacteria were inoculated in LB medium. During Phase I, cultures were grown to an OD600 of 0.6. In Phase II, for engineered bacteria, protein production was induced with $0.1 \mathrm{mM}$ IPTG. Then $120 \mu \mathrm{M} \mathrm{AgNO}_{3}$ was added into the LB medium. For wild-type bacteria, one group had $0 \mu \mathrm{M} \mathrm{AgNO}_{3}$ added to the culture medium, and the other group had $120 \mu \mathrm{M} \mathrm{AgNO}_{3}$ added. The cultures were incubated $\left(37^{\circ} \mathrm{C}, 180 \mathrm{rpm}\right)$ for $1.5 \mathrm{~h}$ in the dark. The concentrations of the bacterial cultures were measured every half hour. This experiment was repeated three times.

\section{LC-MS/MS proteomic analysis}


The total proteins of the E. coli were evaluated using SDS-PAGE. Proteins were extracted and digested according to a previously published method[41]. Detailed information is given in the supplementary information.

\section{List Of Abbreviations}

TEM-EDX: transmission electron microscopy and energy dispersive X-ray spectroscopy; SPRi: surface plasmon resonance imaging; SEM: scanning electron microscopy; EB: engineered bacteria with nanocompartments; WB: wild-type bacteria without nanocompartments; ROS: reactive oxygen species; $\mathrm{WB}+\mathrm{Ag}+\mathrm{WB}+120 \mu \mathrm{M} \mathrm{AgNO}_{3} ; \mathrm{EB}+\mathrm{Ag}+\mathrm{EB}+120 \mu \mathrm{M} \mathrm{AgNO}{ }_{3}$; SDS-PAGE: sodium dodecyl sulfate polyacrylamide gel electrophoresis; GO: Gene Ontology;

\section{Declarations}

\section{Authors' contributions}

CYX,YPC,TFM and JG designed the experiments. CYX and TFM performed the experiments. CYX and TFM analyzed the data and wrote the manuscript. YS, PY and FF were involved in interpretation of results, and fgures and table arrangement. All the authors revised the manuscript. All authors read and approved the fnal manuscript.

\section{Acknowledgements}

We thank Meiji biotechnology company for bioinformatics and analysis.

\section{Availability of data and materials}

The datasets supporting the conclusions of this article are included within the article and its additional fles.

\section{Ethics approval and consent to participate}

Not applicable

\section{Consent for publication}

Not applicable

\section{Conflicts of interest}

There are no conflicts to declare.

\section{Funding}


The authors gratefully acknowledge the supports from the National Natural Science Foundation of China (21876016 and 51578527), the Chongqing Science and Technology Commission (cstc2018jcyjAX0366).

\section{References}

1. Ross-Macdonald P, Coelho PSR, Roemer T, Agarwal S, Kumar A, Jansen R, Cheung KH, Sheehan A, Symoniatis $\mathrm{D}$, Umansky $\mathrm{L}$, et al: Large-scale analysis of the yeast genome by transposon tagging and gene disruption. Nature 1999, 402:413-418.

2. Uetz P, Giot L, Cagney G, Mansfield TA, Judson RS, Knight JR, Lockshon D, Narayan V, Srinivasan M, Pochart P, et al: A comprehensive analysis of protein-protein interactions in Saccharomyces cerevisiae. Nature 2000, 403:623-627.

3. Gavin AC, Aloy P, Grandi P, Krause R, Boesche M, Marzioch M, Rau C, Jensen LJ, Bastuck S, Dumpelfeld B, et al: Proteome survey reveals modularity of the yeast cell machinery. Nature 2006, 440:631-636.

4. Adamis PDB, Panek AD, Eleutherio ECA: Vacuolar compartmentation of the cadmium-glutathione complex protects Saccharomyces cerevisiae from mutagenesis. Toxicol Lett 2007, 173:1-7.

5. Tarze A, Dauplais M, Grigoras I, Lazard M, Ha-Duong NT, Barbier F, Blanquet S, Plateau P: Extracellular production of hydrogen selenide accounts for thiol-assisted toxicity of selenite against Saccharomyces cerevisiae. J Biol Chem 2007, 282:8759-8767.

6. Dernovics M, Far J, Lobinski R: Identification of anionic selenium species in Serich yeast by electrospray QTOF MS/MS and hybrid linear ion trap/orbitrap MSn. Metallomics 2009, 1:317-329.

7. Paulsen IT, Saier MH: A novel family of ubiquitous heavy metal ion transport proteins. J Membrane Biol 1997, 156:99-103.

8. Klaus-Joerger T, Joerger R, Olsson E, Granqvist CG: Bacteria as workers in the living factory: metalaccumulating bacteria and their potential for materials science. Trends Biotechnol 2001, 19:15-20.

9. Nichols RJ, Cassidy-Amstutz C, Chaijarasphong T, Savage DF: Encapsulins: molecular biology of the shell. Crit Rev Biochem Mol Biol 2017, 52:583-594.

10. Kerfeld CA, Heinhorst S, Cannon GC: Bacterial microcompartments. Annu Rev Microbio/ 2010, 64:391-408.

11. Savage DF, Afonso B, Chen AH, Silver PA: Spatially Ordered Dynamics of the Bacterial Carbon Fixation Machinery. Science 2010, 327:1258-1261.

12. Held M, Quin MB, Schmidt-Dannert C: Eut Bacterial Microcompartments: Insights into Their Function, Structure, and Bioengineering Applications. J Mol Microb Biotech 2013, 23:308-320.

13. Kramer RM, Li C, Carter DC, Stone MO, Naik RR: Engineered protein cages for nanomaterial synthesis. J Am Chem Soc 2004, 126:13282-13286.

14. Li F, Wang Q: Fabrication of nanoarchitectures templated by virus-based nanoparticles: strategies and applications. Small 2014, 10:230-245. 
15. Li F, Chen Y, Chen H, He W, Zhang ZP, Zhang XE, Wang Q: Monofunctionalization of protein nanocages. J Am Chem Soc 2011, 133:20040-20043.

16. Li F, Gao D, Zhai X, Chen Y, Fu T, Wu D, Zhang ZP, Zhang XE, Wang Q: Tunable, discrete, threedimensional hybrid nanoarchitectures. Angew Chem Int Ed Eng/2011, 50:4202-4205.

17. Pokorski JK, Steinmetz NF: The art of engineering viral nanoparticles. Mol Pharm 2011, 8:29-43.

18. Huang RY, He L, Zhang T, Li DQ, Tang PG, Feng YJ: Novel Carbon Paper@Magnesium Silicate Composite Porous Films: Design, Fabrication, and Adsorption Behavior for Heavy Metal lons in Aqueous Solution. Acs Appl Mater Inter 2018, 10:22776-22785.

19. Cantuaria ML, de Almeida Neto AF, Nascimento ES, Vieira MGA: Adsorption of silver from aqueous solution onto pre-treated bentonite clay: complete batch system evaluation. J Clean Prod 2016, 112:1112-1121.

20. Jesus Munoz A, Espinola F, Ruiz E: Biosorption of Ag(I) from aqueous solutions by Kiebsiella sp 3S1. $J$ Hazard Mater 2017, 329:166-177.

21. Valdesstauber N, Scherer S: ISOLATION AND CHARACTERIZATION OF LINOCIN M18, A BACTERIOCIN PRODUCED BY BREVIBACTERIUM LINENS. App/ Environ Microb 1994, 60:3809-3814.

22. Rosenkrands I, Rasmussen PB, Carnio $M$, Jacobsen $S$, Theisen $M$, Andersen P: Identification and characterization of a 29-kilodalton protein from Mycobacterium tuberculosis culture filtrate recognized by mouse memory effector cells. Infect Immun 1998, 66:2728-2735.

23. Campbell CT, Kim G: SPR microscopy and its applications to high-throughput analyses of biomolecular binding events and their kinetics. Biomaterials 2007, 28:2380-2392.

24. Yao J, Stewart ME, Maria J, Lee TW, Gray SK, Rogers JA, Nuzzo RG: Seeing molecules by eye: surface plasmon resonance imaging at visible wavelengths with high spatial resolution and submonolayer sensitivity. Angew Chem Int Ed Eng/ 2008, 47:5013-5017.

25. Homola J: Surface plasmon resonance sensors for detection of chemical and biological species. Chem Rev 2008, 108:462-493.

26. Wang S, Shan X, Patel U, Huang X, Lu J, Li J, Tao N: Label-free imaging, detection, and mass measurement of single viruses by surface plasmon resonance. Proc Natl Acad Sci U S A 2010, 107:16028-16032.

27. Wang W, Yang Y, Wang S, Nagaraj VJ, Liu Q, Wu J, Tao N: Label-free measuring and mapping of binding kinetics of membrane proteins in single living cells. Nat Chem 2012, 4:846-853.

28. Putri RM, Allende-Ballestero C, Luque D, Klem R, Rousou KA, Liu A, Traulsen CH, Rurup WF, Koay MST, Caston JR, Cornelissen J: Structural Characterization of Native and Modified Encapsulins as Nanoplatforms for in Vitro Catalysis and Cellular Uptake. ACS Nano 2017, 11:12796-12804.

29. Rahmanpour R, Bugg TDH: Assemblyin vitroofRhodococcus jostii RHA1 encapsulin and peroxidase DypB to form a nanocompartment. FEBS J 2013, 280:2097-2104.

30. Said J, Dodoo CC, Walker M, Parsons D, Stapleton P, Beezer AE, Gaisford S: An in vitro test of the efficacy of silver-containing wound dressings against Staphylococcus aureus and Pseudomonas 
aeruginosa in simulated wound fluid. Int J Pharm 2014, 462:123-128.

31. Marambio-Jones C, Hoek EMV: A review of the antibacterial effects of silver nanomaterials and potential implications for human health and the environment. J Nanopart Res 2010, 12:1531-1551.

32. Chasteen ND, Harrison PM: Mineralization in ferritin: An efficient means of iron storage. J Struct Biol 1999, 126:182-194.

33. Chasteen ND: Ferritin. Uptake, storage, and release of iron. Metal ions in biological systems 1998, 35:479-514.

34. Sutter M, Boehringer D, Gutmann S, Günther S, Prangishvili D, Loessner MJ, Stetter KO, Weber-Ban E, Ban N: Structural basis of enzyme encapsulation into a bacterial nanocompartment. Nat Struct Mol Biol 2008, 15:939-947.

35. Akita F, Chong KT, Tanaka H, Yamashita E, Miyazaki N, Nakaishi Y, Suzuki M, Namba K, Ono Y, Tsukihara T, Nakagawa A: The Crystal Structure of a Virus-like Particle from the Hyperthermophilic Archaeon Pyrococcus furiosus Provides Insight into the Evolution of Viruses. J Mol Biol 2007, 368:1469-1483.

36. Gupta A, Matsui K, Lo JF, Silver S: Molecular basis for resistance to silver cations in Salmonella. Nat Med 1999, 5:183-188.

37. Wang H, Yan A, Liu Z, Yang X, Xu Z, Wang Y, Wang R, Koohi-Moghadam M, Hu L, Xia W, et al:

Deciphering molecular mechanism of silver by integrated omic approaches enables enhancing its antimicrobial efficacy in E. coli. Plos Biol2019, 17.

38. Giessen TW, Silver PA: Widespread distribution of encapsulin nanocompartments reveals functional diversity. Nat Microbiol 2017, 2.

39. Howarter JA, Youngblood JP: Optimization of silica silanization by 3-aminopropyltriethoxysilane. Langmuir 2006, 22:11142-11147.

40. Shan X, Diez-Perez I, Wang L, Wiktor P, Gu Y, Zhang L, Wang W, Lu J, Wang S, Gong Q, et al: Imaging the electrocatalytic activity of single nanoparticles. Nat Nanotechnol 2012, 7:668-672.

41. Yin X, Zhang Y, Liu X, Chen C, Lu H, Shen H, Yang P: Systematic comparison between SDSPAGE/RPLC and high-/low-pH RPLC coupled tandem mass spectrometry strategies in a whole proteome analysis. Analyst 2015, 140:1314-1322.

\section{Figures}



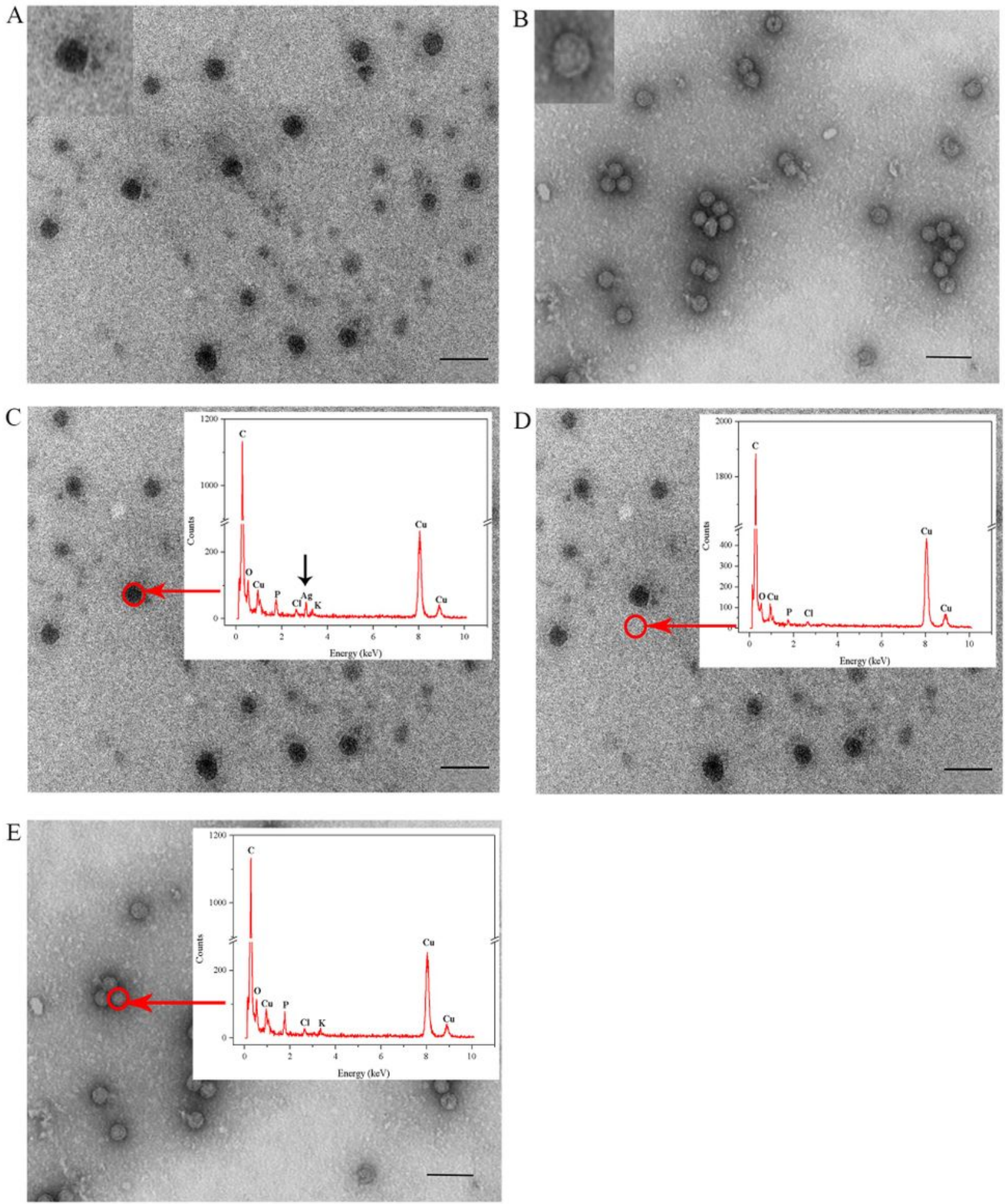

\section{Figure 1}

Nanocompartments encapsulating silver ions in vitro. (A) Transmission electron micrographs of a nanocompartment with silver ions. (B) Nanocompartment without silver ions. (C) Nanocompartment particle measurement showing elevated silver peaks by TEM-EDX (red circles). (D) Nonnanocompartment measurement. (E) Empty nanocompartment measurement. Scale bars, $200 \mathrm{~nm}$. 
A
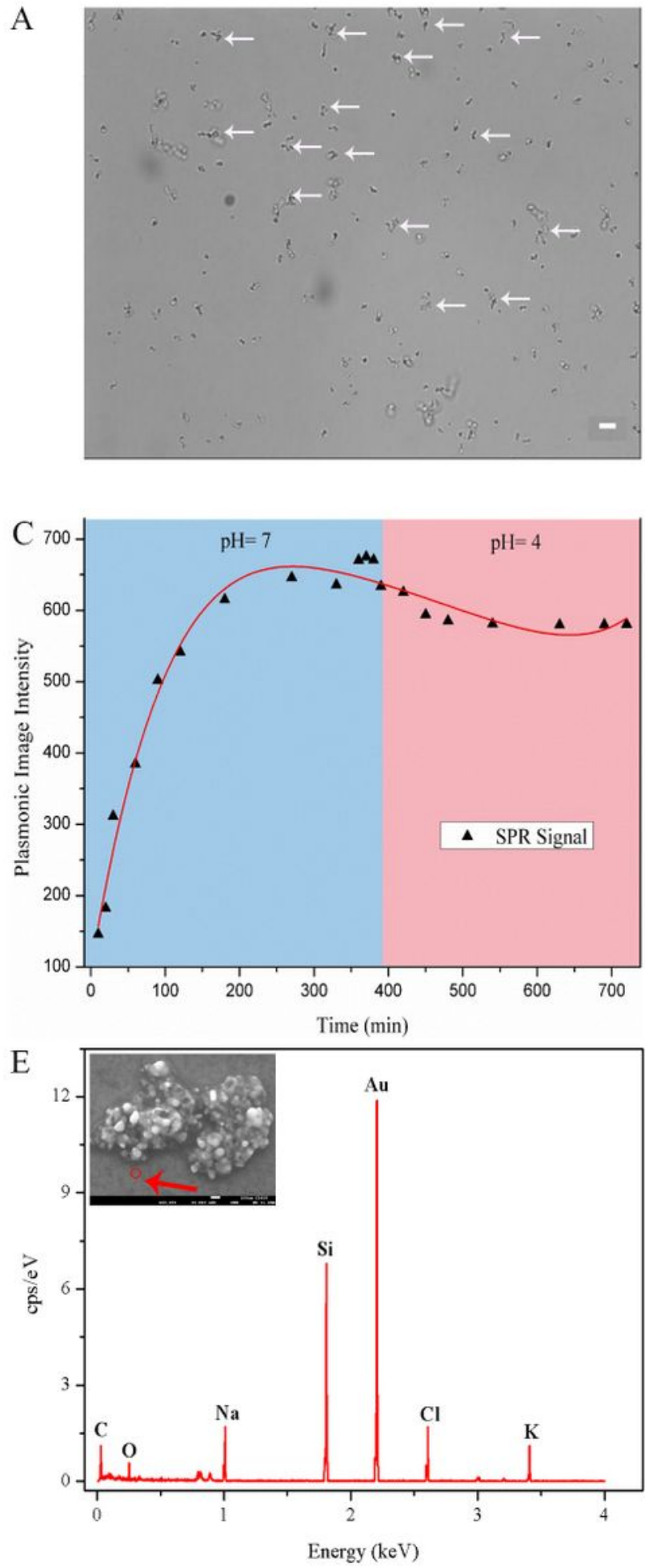

B
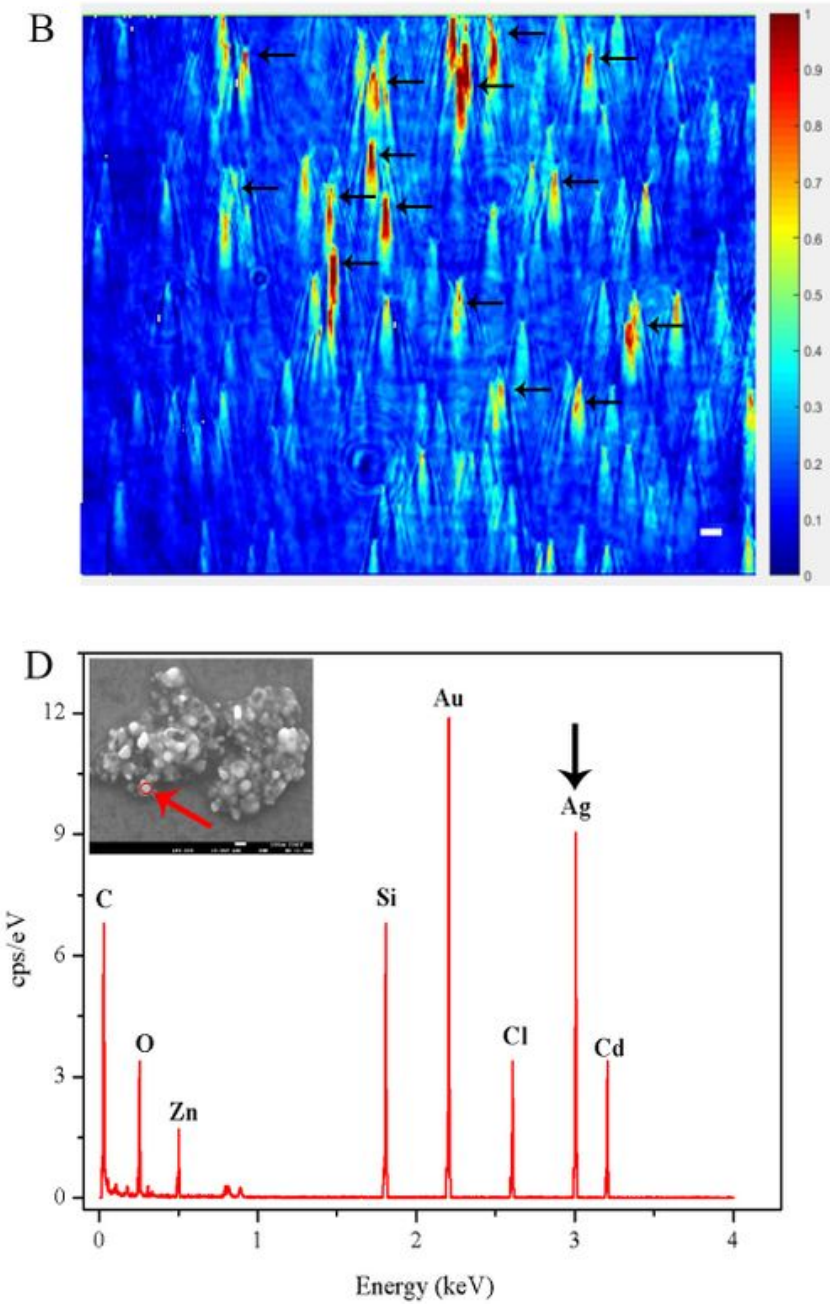

\section{Figure 2}

Agglomeration/dispersion of nanocompartment encapsulated silver ions. (A) Brightfield image of nanocompartment particles. (B) Plasmonic image of the encapsulin nanocompartment. Scale bars, $2 \mu \mathrm{m}$. (C) Sensorgrams of nanocompartment particles. (D) SEM-EDX (red circles) measurement of nanocompartment particles on the chip showing an elevated silver peak and $(E)$ measurement of a nonnanocompartment chip section. Scale bars, $100 \mathrm{~nm}$. 
A

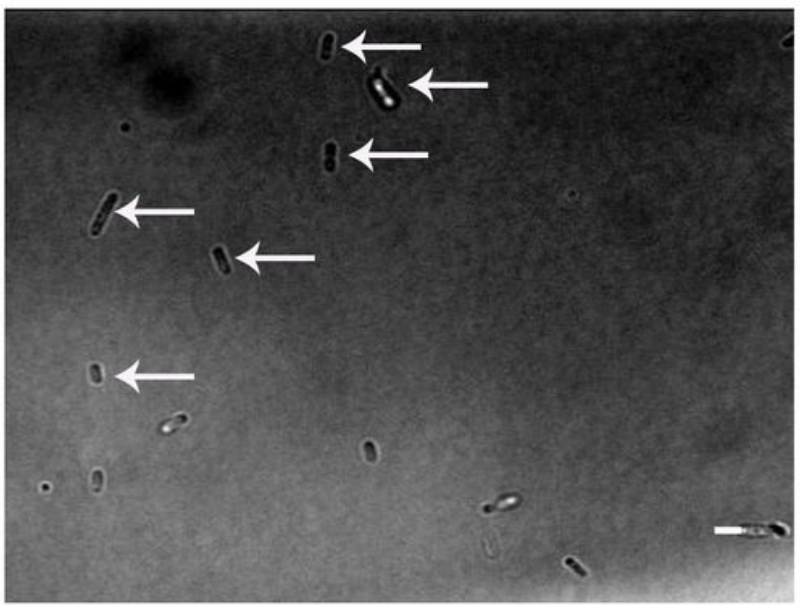

$\mathrm{C}$

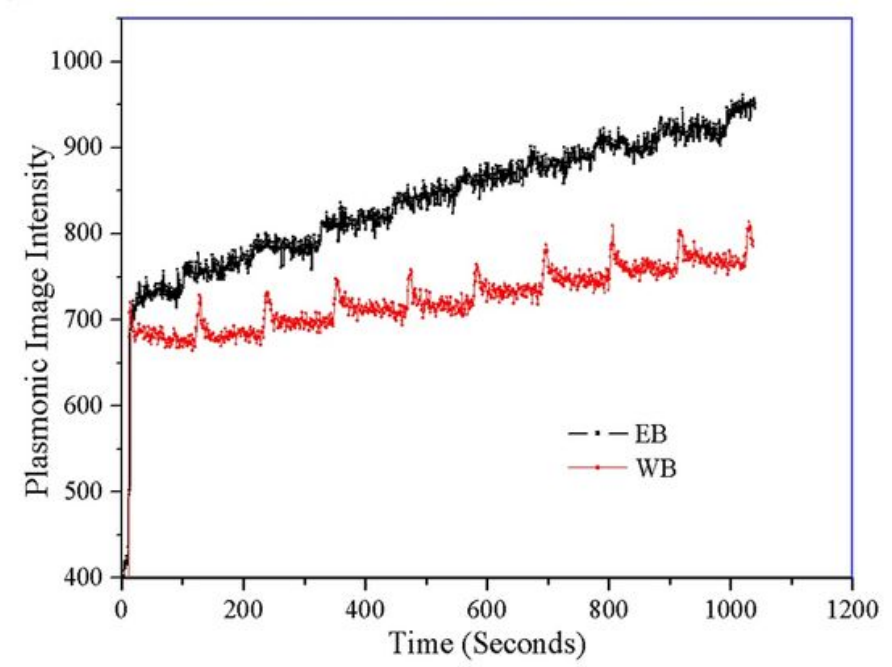

$\mathrm{B}$

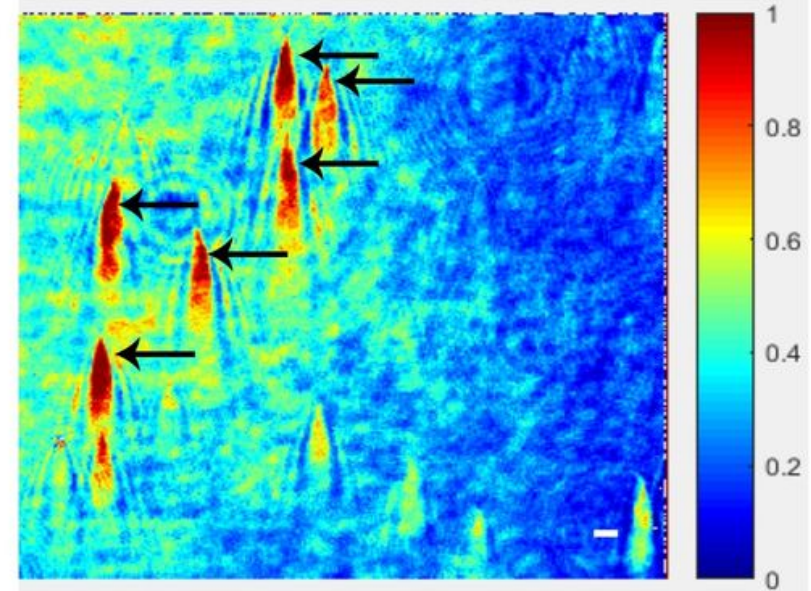

D

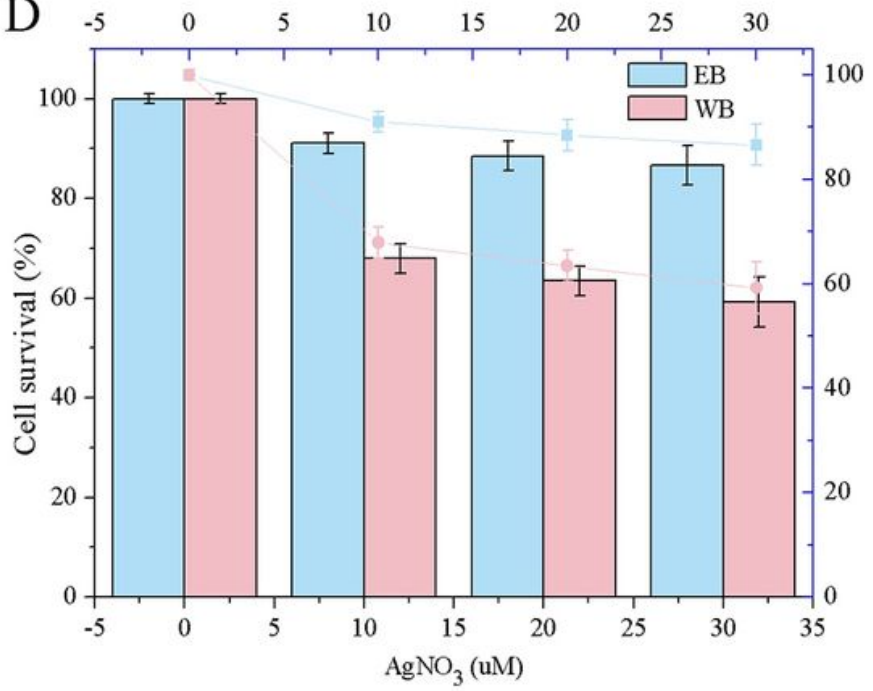

Figure 3

The nanocompartments helped the bacteria resist silver ion stress. (A) Brightfield image of bacterial cells. (B) Plasmonic image of the bacteria. Scale bars, $2 \mu \mathrm{m}$. (C) EB, E. coli with nanocompartments (black line); sensorgram of WB, E. coli without nanocompartments (red line). The number of bacteria in each group was 20. (D) Cell survival of EB (blue line) and WB (red line) with different concentrations of AgNO3 ( $0 \mu \mathrm{M}$, $10 \mu \mathrm{M}, 20 \mu \mathrm{M}$, and $30 \mu \mathrm{M})$. 
A

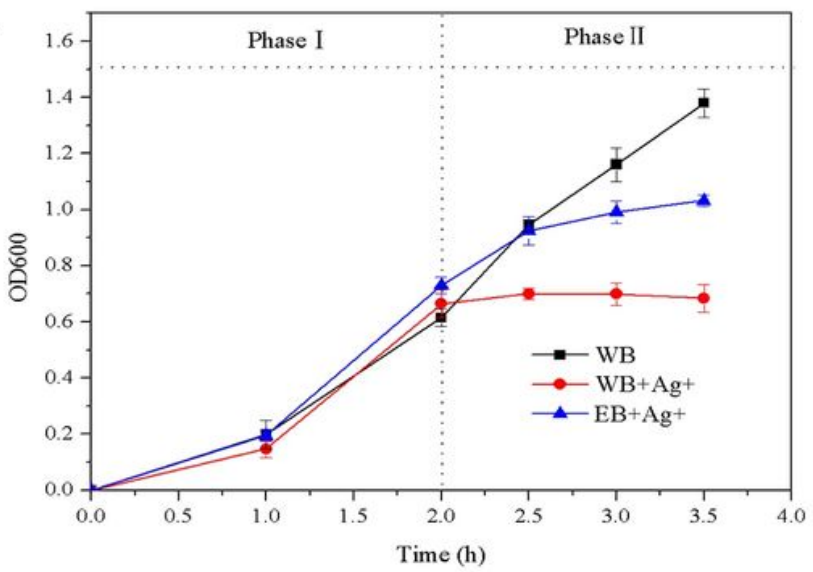

C GO annotation analysis (level 2)

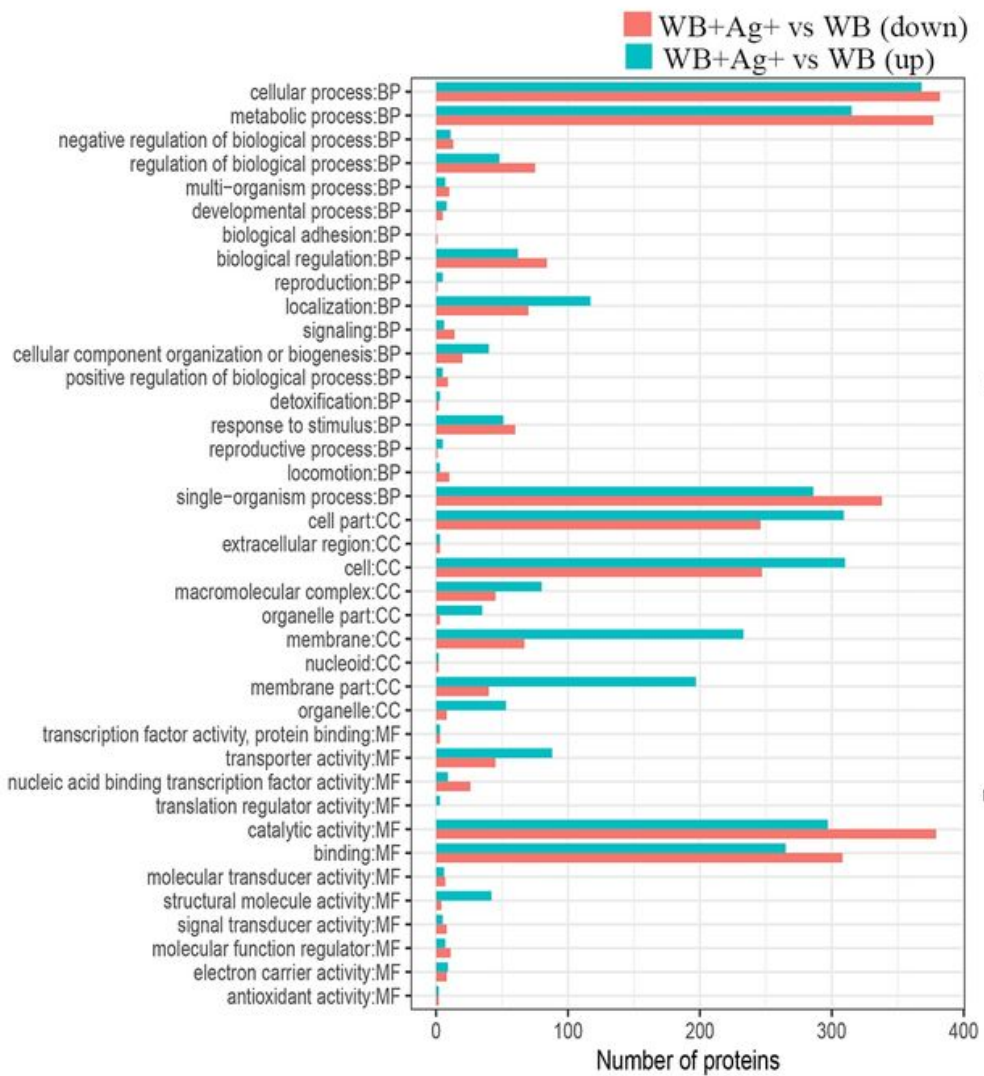

B

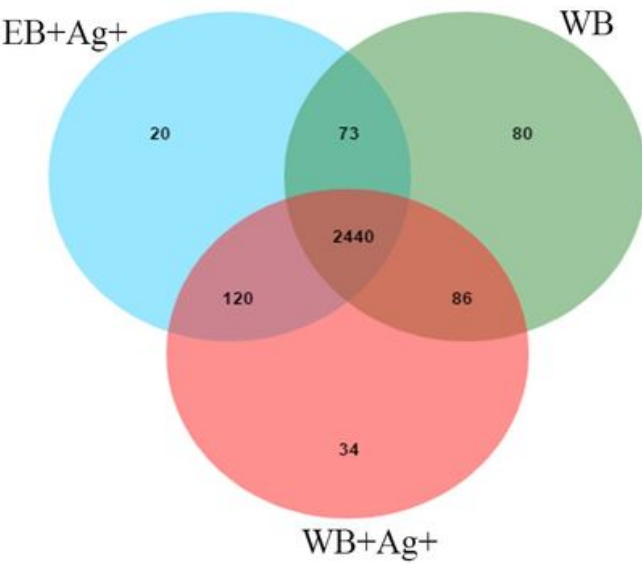

D

GO annotation analysis (level 2)

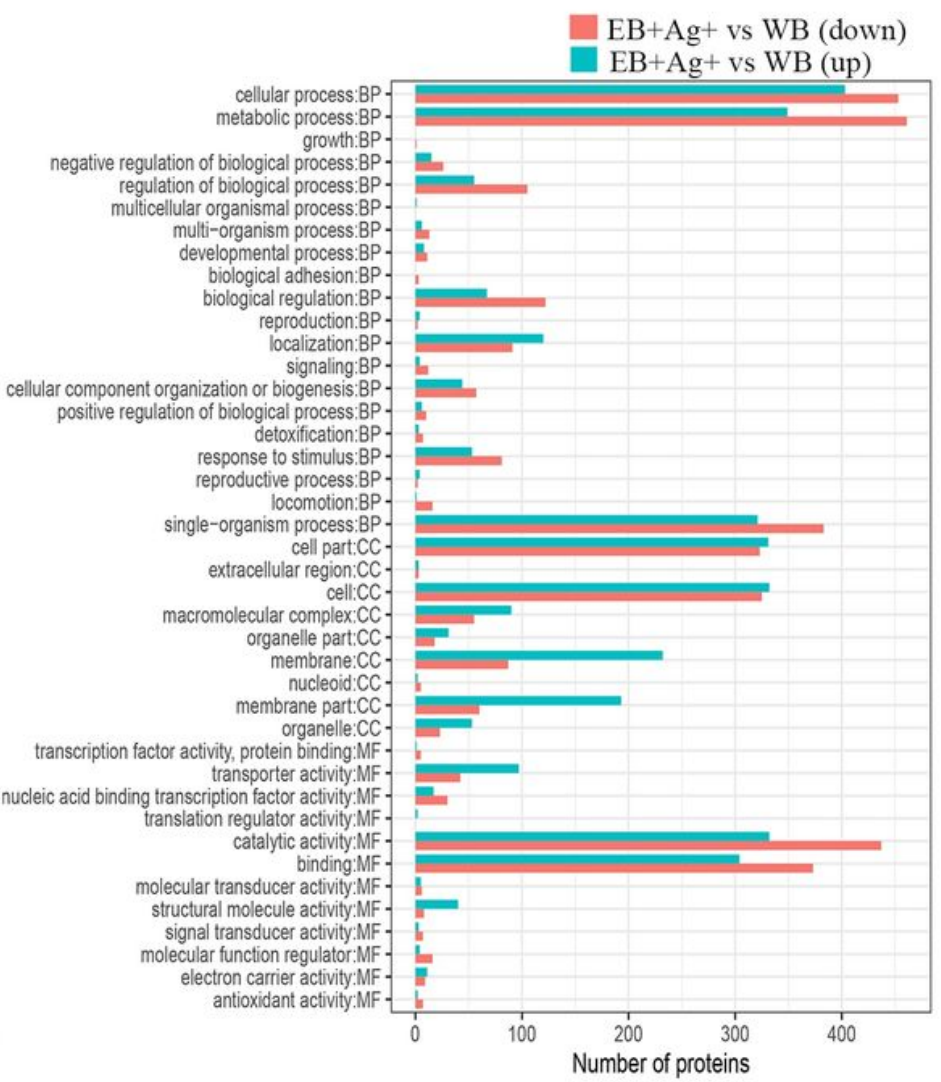

\section{Figure 4}

High-throughput proteomics. (A) Cell growth curve of wild-type bacteria without AgNO3 (WB, black line), wild-type bacteria with $120 \mu \mathrm{M}$ AgNO3 (WB+Ag+, red line), and engineered bacteria with $120 \mu \mathrm{M}$ AgNO3 $(E B+A g+$, blue line). Each group of samples had three biological replicates. $(B)$ Venn diagram showing the occurrence of the proteins detected in the different bacteria groups. (C) and (D), GO annotation analyses (Level 2). (C) Differentially expressed proteins of 'WB+Ag+ vs WB'. (D) Differentially expressed proteins of 'EB+Ag+ vs WB'. 
A

Go enrichment analysis (WB+Ag+vs WB, up)

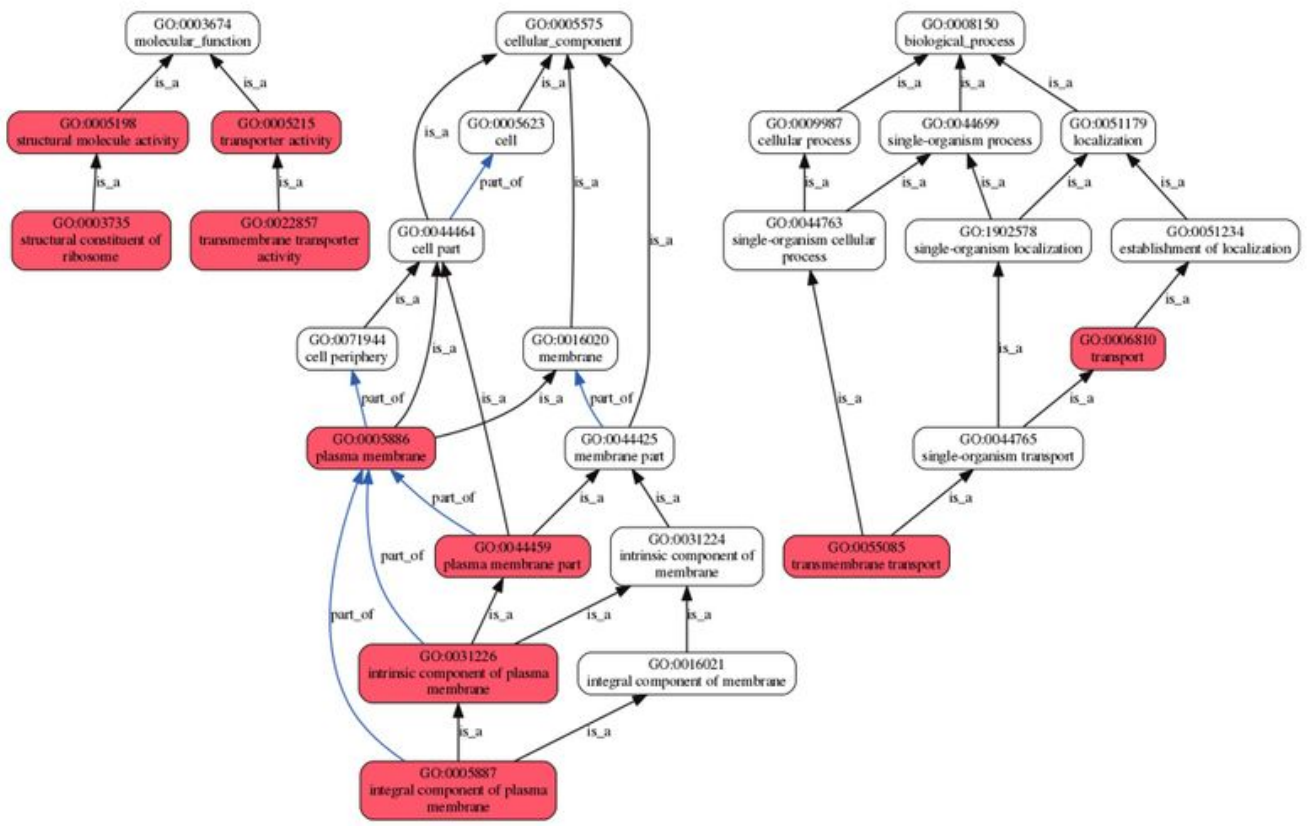

B

Go enrichment analysis (EB+Ag+ vs WB, up)

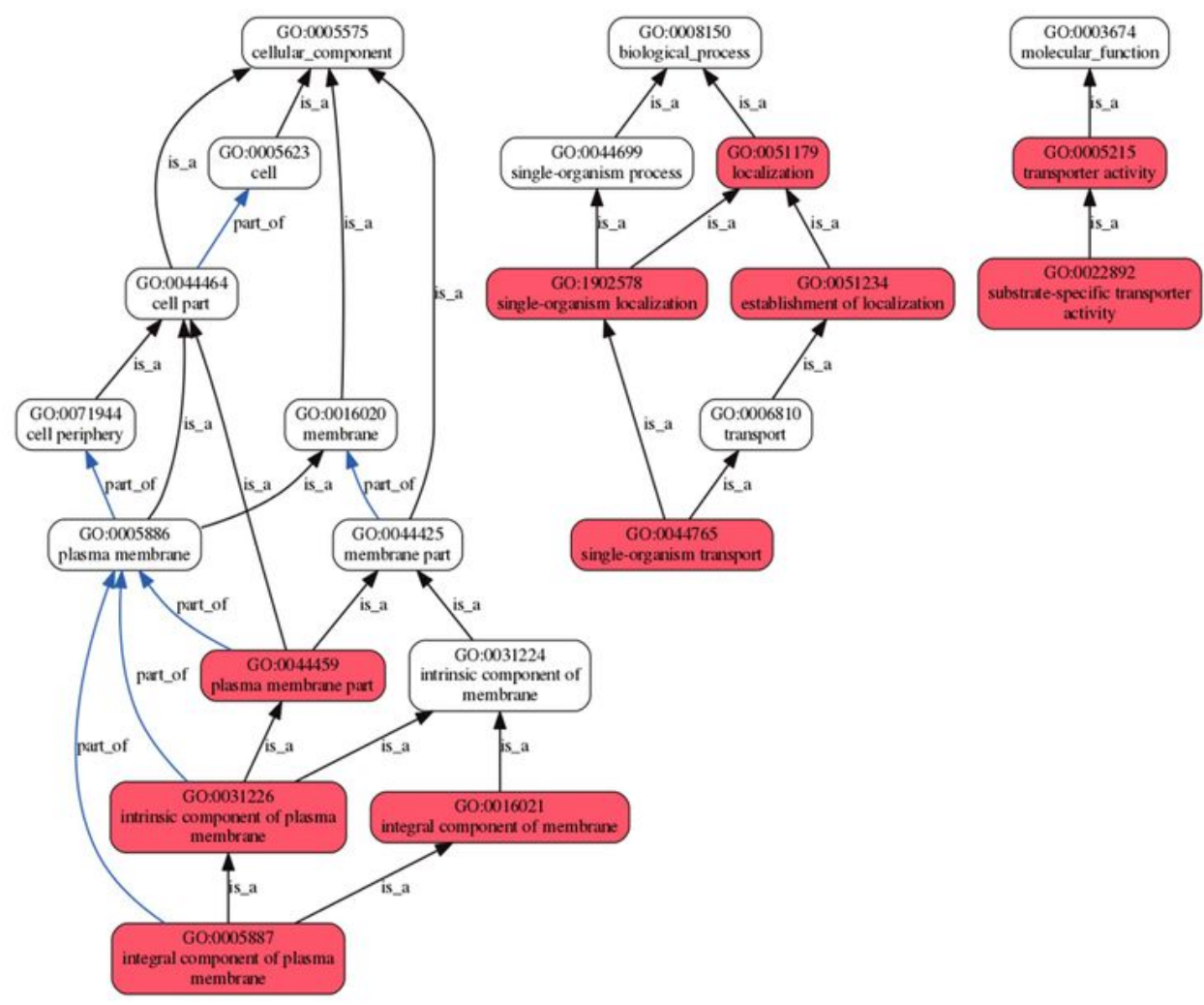

Figure 5

GO enrichment analyses of the up-regulated proteins in ' $W B+A g+v s W B$ ' and ' $E B+A g+v s W B$ '. The red functional units show up-regulation of proteins. 
A

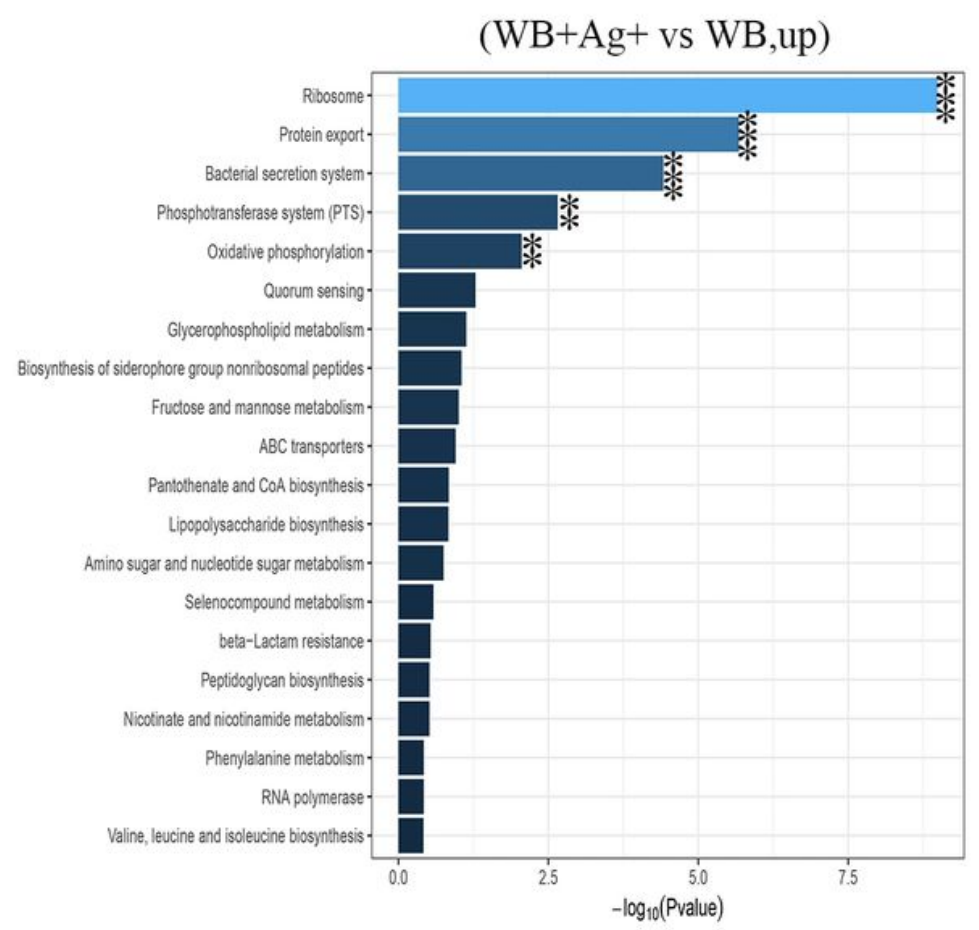

B

KEGG enrichment analysis

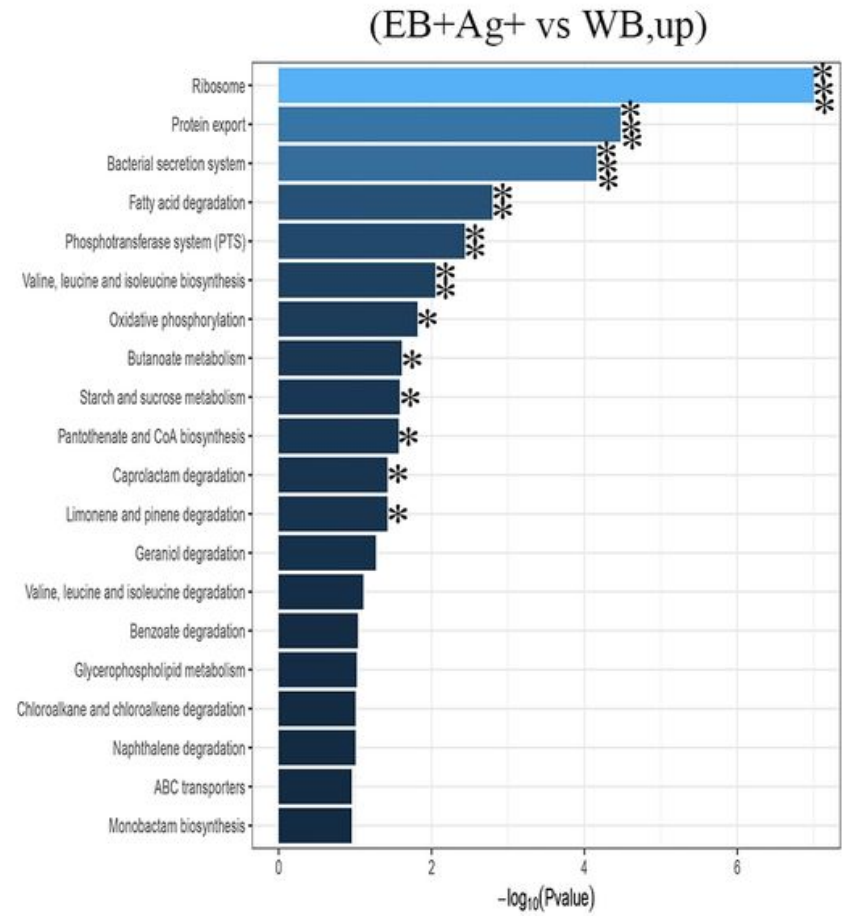

Figure 6

KEGG enrichment analyses of the up-regulated proteins in the 'WB+Ag+ vs WB' and 'EB+Ag+ vs WB'. $P<$ 0.001 is marked as ***, $\mathrm{P}<0.01$ is marked as **, and $\mathrm{P}<0.05$ is marked as *. 


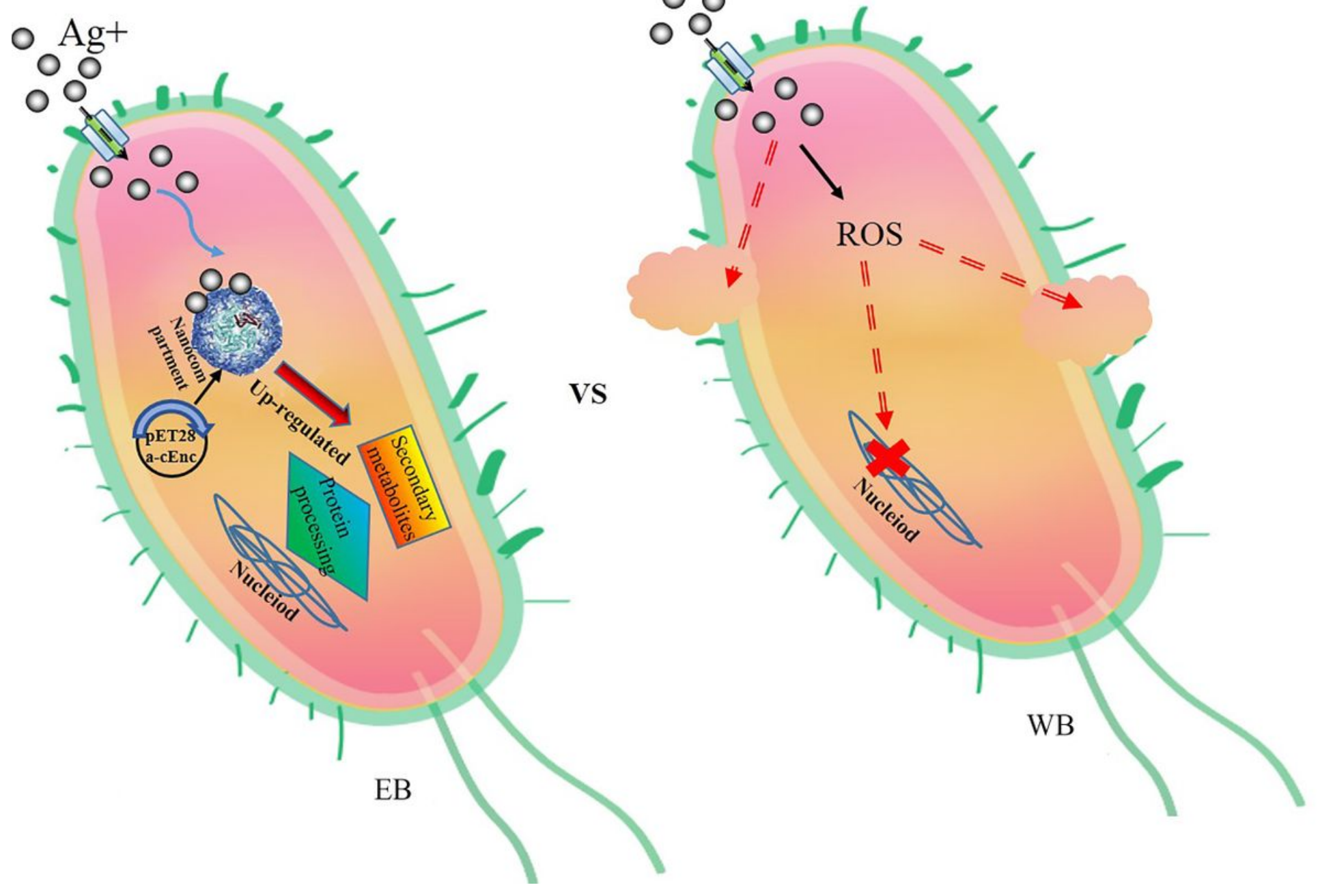

Figure 7

Schematic of potentially involved mechanisms in nanocompartment protection of E. coli (EB, E. coli with nanocompartments; WB, E. coli without nanocompartments) against silver ion stress. Silver ions (Ag+) enter the cell, and then produce ROS that break down cell membranes and DNA, leading to cell lysis. Nanocompartments can sequester the silver ions and induce up-regulation of protein processing and secondary metabolites, thereby protecting the cell from silver ion stress.

\section{Supplementary Files}

This is a list of supplementary files associated with this preprint. Click to download.

- SupplementaryFiles.zip 